\title{
Sustainable Inclusion of Smallholders in the Emerging High Quality Cassava Flour Value Chains in Africa: Challenges for Agricultural Extension Services
}

\author{
Adebayo, K1 .; Abayomi, L. ${ }^{1}$; Abass, A. ${ }^{2}$; Dziedzoave, N. T. ${ }^{3}$; Forsythe, L. ${ }^{1}$; \\ Hillocks, R. J. ${ }^{1}$; Gensi, R. ${ }^{4}$; Gibson, R. W. ${ }^{1}$; Graffham, A. J. ${ }^{1}$; Ilona, P. ${ }^{2}$; Kleih, U. \\ K. ' ; Lamboll, R. I. ' ; Mahende, G. ${ }^{5}$; Martin, A. M ${ }^{1}$; Onumah, G. E. ' ; Orr, A. W. ${ }^{1}$; \\ Posthumus, $\mathrm{H}^{1}$.; Sanni, L. O. ${ }^{6}$; Sandifolo, V. ${ }^{7}$ and Westby, A. ${ }^{1}$ \\ Natural Resources Institute, University of Greenwich, Chatham, United Kingdom \\ E-mail: k.adebayo@greenwich.ac.uk Phone: +447747376730 \\ International Institute of Tropical Agriculture, Ibadan, Nigeria \\ 3. Food Research Institute, Accra, Ghana \\ 4. African Innovations Institute, Kampala, Uganda \\ 5. Tanzanian Food and Nutrition Centre, Dares Salaam, Tanzania \\ 6. University of Agriculture, Abeokuta, Nigeria \\ 7. Chancellor College, University of Malawi, Zomba, Malawi
}

\begin{abstract}
Based on the premise that smallholders often get excluded as markets become more commercial, this paper draws lessons from the Cassava: Adding Value for Africa (C:AVA) Project by exploring the main issues and challenges facing extension service partners in five African countries (Nigeria, Ghana, Tanzania, Uganda and Malawi). These lessons include issues around competiveness in the supply of raw material, assisting smallholders to produce value-added products competitively, working with a range of partners at different stages in the value chain to take pilot studies to scale, ensuring and maintaining quality, selecting appropriate technologies for different circumstances, anticipating negative effects of the market environment on smallholders and ensuring that strategies for ensuring benefits for women and other disadvantaged groups are incorporated into extension service operations. It concluded that one strategy does not work in all countries and, while positive government support for cassava development is helpful, the real challenge is in the need to target markets according to realisable capacities of the smallholder actors in the value chain.
\end{abstract}

\section{Introduction}

Cassava is one of the most important food crops of Africa. Its high resilience and adaptability to a wide range of ecological conditions has sustained its production through many generations in sub-Saharan Africa since it was introduced into this region in the $16^{\text {th }}$ century (Adebayo et al., 2009). It is consumed in different traditional dishes varying from country to country and across communities in a country (Adebayo, 2006). It is cultivated in the humid forest zones and the sub humid savanna of Africa and South America and in some part of Asia. It provides increased income for farming households; increased employment opportunities; potential to target development benefits to women; potential lower food prices for consumers; competitively priced raw materials and more convenience e.g. improved traditional products. Current studies have however identified clear gaps in the market for some cassava products in Africa (Table 1). In particular, a number of highly promising industrial and commercial use clusters have been identified (NEPAD, 2004; Sanni, 2005). The potential for further growth of fresh root and traditional processed products is limited because markets are generally saturated and growth will be mainly related to population increase. 
The most promising market to develop is that of high quality cassava flour (HQCF) and its use as a replacement for wheat flour in the bakery sector, in plywood manufacture and also as an alternative or component in traditional cassava products (e.g. instant fufu in Ghana; fermented fufu in Nigeria). The main reasons for focusing on HQCF are that value can be added at the rural household level by processing of the intermediate product (cassava grits or wet paste), thereby increasing incomes for farmers; the requirements for capital investment is lower and less environmental damage is caused than starch manufacture; and many farmers already know how to create the basic raw material for HQCF (grated cassava). Therefore a huge technology leap at the farmer level is not required to attain the developmental objective. Consequently, HQCF offers the easiest entry point, benefits the most smallholder farmers/processors in the immediate future and provides a springboard for investment in other products.

Table 1: Assessment of potential market opportunities for cassava roots in Africa

\begin{tabular}{|l|l|l|l|l|}
\hline Product & $\begin{array}{l}\text { Current } \\
\text { Importance }\end{array}$ & $\begin{array}{l}\text { Potential } \\
\text { growth -low } \\
\text { investment }\end{array}$ & $\begin{array}{l}\text { Potential } \\
\text { growth } \\
\text { high } \\
\text { investment }\end{array}$ & $\begin{array}{l}\text { Export } \\
\text { potential }\end{array}$ \\
\hline HQCF for bakery use & Low & High & High & Some \\
\hline $\begin{array}{l}\text { Improved version of } \\
\text { traditional products } \\
\text { (that use HQCF) }\end{array}$ & Very low & High & High & $\begin{array}{l}\text { Some - but } \\
\text { low }\end{array}$ \\
\hline $\begin{array}{l}\text { Industrial uses from } \\
\text { Chips and Flours } \\
\text { (e.g. Low plywood/ } \\
\text { paperboard) (that } \\
\text { use HQCF) }\end{array}$ & High & High & Difficult \\
\hline Animal feed added & None & Marginal & Possible & Difficult \\
\hline $\begin{array}{l}\text { Bio-ethanol how } \\
\text { Starch (modified) }\end{array}$ & Lery low & Some & High & Difficult/Some \\
\hline $\begin{array}{l}\text { Value } \\
\text { products e.g MSG }\end{array}$ & Motentially & Possible \\
\hline $\begin{array}{l}\text { Traditional processed } \\
\text { products }\end{array}$ & High & Low & Low & $\begin{array}{l}\text { Some - but } \\
\text { low }\end{array}$ \\
\hline Fresh roots & High & Low & Low & v. low \\
\hline
\end{tabular}

Against this background, the Cassava: Adding Value for Africa Project (C:AVA) is supported by the Bill and Melinda Gates Foundation to provide an example of a value chain project aimed at linking small-scale cassava farmers with growth markets. Value chains for HQCF are being developed in five African countries (Nigeria, Ghana, Tanzania, Uganda and Malawi) to improve the livelihoods and incomes of at least 90,000 smallholder households, including women and disadvantaged groups. C:AVA aims to promote HQCF as a versatile raw material for which diverse markets exist. This paper therefore draws lessons from the interaction 
created by the C:AVA Project to explore the main issues and challenges facing extension service partners in the five African countries.

\section{C:AVA Project Approach}

The C:AVA project approach is based mainly on three most potent intervention points to develop HQCF values chains (Table 2). Intervening at these critical points has been shown to have strong potential for sustainable value chains development in the HQCF market (UNAAB, 2007; van Oirschot et al, 2004; Adebayo, et al, 2003; Dipeolu et al, 2003; Dipeolu et al, 2001). The three intervention points are the priorities for this project and form the basis of Project Objectives. The key activities at these intervention points include enhancing access to finance, business skills, and appropriate technologies; ensuring quality of products and reliability of supply; and integration of activities within the value chain. Although there are a number of end-uses for HQCF, the project focuses on two of the highest volume end-uses of HQCF in each of the countries. These are shown in Table 3 with an indication of the cassava production levels.

Table 2. The potent intervention points in the HQCF value chain

\begin{tabular}{|c|c|c|}
\hline & Potent intervention points & Determinants of success \\
\hline 1 & $\begin{array}{l}\text { Ensuring consistent supply of } \\
\text { quality raw materials (roots } \\
\text { and grits) }\end{array}$ & $\begin{array}{l}\text { Ability of farmers to profitably produce grits or } \\
\text { roots at a competitive price. The supply must be } \\
\text { sufficient and reliable in terms of volume and } \\
\text { quality to sustain processing operations. }\end{array}$ \\
\hline 2 & $\begin{array}{l}\text { Developing financially-viable } \\
\text { intermediaries }\end{array}$ & $\begin{array}{l}\text { Ability to buy either roots or grits from farmers, } \\
\text { assemble them and make and sell consistent } \\
\text { high quality HQCF to end users. }\end{array}$ \\
\hline 3 & $\begin{array}{l}\text { Ensuring the confidence of } \\
\text { end users of HQCF as a food } \\
\text { ingredient }\end{array}$ & $\begin{array}{l}\text { Availability of a consistent supply of } \\
\text { competitively priced HQCF of sufficient quality }\end{array}$ \\
\hline
\end{tabular}

Two Regions or States or Zones were selected in each project country where farmers and processors were supported in cassava production and primary processing activities through partnership with NGOs or other extension services (Table 4). Business development and other specialists support were provided to intermediary enterprises to meet the requirements of end users of HQCF, and end users are being supported in adopting HQCF. This way, the project intends to increase incomes of smallholder households significantly beyond its life. Additional benefits including employment, reduced raw material costs, reduced need to import wheat, development of capacity to upgrade other value chains, and potentially export HQCF are also expected. Strong roles of national partners are expected to lead to higher levels of sustainability of project gains. To this extent, in each of the five operating countries, extension service providers are contracted to provide services to cassava farmers and processors that would improve cassava cultivation and postharvest handling in ways that will add value to the crop and benefit the extension clientele. 


\begin{tabular}{|l|l|l|l|} 
Table 3. Reasons for the selection of specific countries and the uses of \\
HQCF per country
\end{tabular}

${ }^{a}$ FAOSTAT 2005 data

Table 4. Focus regions/states/zones per country

\begin{tabular}{|l|l|l|l|l|l|}
\hline & Ghana & Nigeria & Tanzania & Uganda & Malawi \\
\hline Region 1 & Brong Ahafo & Ogun & Eastern & Eastern & Central/Northern \\
& Region & State & Zone & Region & Region \\
\hline Region 2 & Volta Region & $\begin{array}{l}\text { Ondo } \\
\text { State }\end{array}$ & $\begin{array}{l}\text { Southern } \\
\text { Zone }\end{array}$ & $\begin{array}{l}\text { Northern } \\
\text { Region }\end{array}$ & Central Region \\
\end{tabular}

The list of contracted extension service providers are shown in Table 5. These include government or NGO extensionists, farmer associations, representatives and researchers. This arrangement occurs in Africa for commercial crops such as tobacco in Tanzania/Uganda, and cotton in Uganda, but not in the cassava subsector, though it was successfully employed on a small scale in Ghana and Nigeria (UNAAB, 2007). Both farmers and intermediary enterprises are benefiting and 
because current advisory services are being concurrently strengthened, no monopoly over information or materials is created.

Table 5. Extension service providers working with the C:AVA Project ${ }^{\star}$ Name

\begin{tabular}{|l|l|}
\hline $\begin{array}{l}\text { UNAAB - Agricultural Media Resources and Extension Centre (UNAAB- } \\
\text { AMREC) }\end{array}$ & Nigeria \\
\hline Country Women Association of Nigeria (COWAN) & Nigeria \\
\hline Justice, Peace and Development Movement, Nigeria (JDPM) & Nigeria \\
\hline Ogun State Agricultural Development Programme, Nigeria (OGADEP) & Nigeria \\
\hline Ondo State Agricultural Development Programme, Nigeria (ONADEP) & Nigeria \\
\hline Christ Apostolic Agency for Rural Development, Ghana (CAARD) & Ghana \\
\hline $\begin{array}{l}\text { Volta Directorate of the Ministry of Food and Agriculture, Ghana (MOFA- } \\
\text { VR) }\end{array}$ & Ghana \\
\hline Progressive Youth in Community Development, Ghana (PROYCOD) & Ghana \\
\hline Christian Rural Aid Network (CRAN), Ghana & Ghana \\
\hline $\begin{array}{l}\text { Brong Ahafo Directorate of the Ministry of Food and Agriculture (MOFA - } \\
\text { BA) }\end{array}$ & Ghana \\
\hline The Social Development and Improvement Agency (SODIA) & Ghana \\
\hline The Associates for Sustainable Rural Development (ASRuD) & Ghana \\
\hline Association of African Woman in Development (AAWID) & Ghana \\
\hline $\begin{array}{l}\text { Farming for Food and Development Program - Eastern Uganda (FADEP- } \\
\text { EU) }\end{array}$ & Uganda \\
\hline Matilong Community Development Organization (MACDO) & Uganda \\
\hline VISION TERUDO & Uganda \\
\hline Masasi Peoples Umbrella Organization/Kikundi Mwavuli Masasi (KIMAS) & Tanzania \\
\hline United Peasants of Tanzania (UPT) & Tanzania \\
\hline District Agricultural and Livestock Development Office (DALDO), Newala & Tanzania \\
\hline District Agricultural and Livestock Development Office (DALDO), Masasi & Tanzania \\
\hline District Agricultural and Livestock Development Office (DALDO), Mtwara & Tanzania \\
\hline $\begin{array}{l}\text { District Agricultural and Livestock Development Office (DALDO), } \\
\text { Tandahimba }\end{array}$ & Tanzania \\
* The contracting of extension service providers for Malawi is not yet concluded due to the staggered \\
nature of project commencement in the different countries
\end{tabular}

\section{Lessons and Challenges for Extension Services}

Competiveness of the raw material and assisting smallholders to produce valueadded products competitively

In commercial interactions, competition is often encouraged as a means of ensuring quality and maintaining reasonable prices. Two forms for competition are prevalent at the smallholder level in the HQCF value chain. These are the competition to supply raw materials (cassava roots, grits or wet pastes) for alternative uses and the competition to meet quality and quantity requirements of larger scale buyers. In the first case, the challenge for extension services is to understand that smallholders have alternative uses for the cassava roots, grits and wet pastes other than the HQCF value chain. This may be cassava roots directed to gari or other traditional foods value chain or cassava grits of lower quality directed to lower quality cassava flour value chains such as lafun or cassava wet pastes meant for the fermented wet pastes value chain to be served as traditional fufu or agbelima. 
This understanding will enable extension services to work with smallholders in ways that acknowledge the needs of these other value chains as they try to work with smallholders to develop and contribute to the emerging chain for HQCF.

In the second case, large scale buyers of cassava roots, grits or wet pastes often make requirements for quantity and quality of raw materials that are not easily met by smallholders. This may include requirements concerning minimum quantity of raw materials that they will be willing to take from smallholders or specific level of whiteness or $\mathrm{pH}$ in the cassava grits or wet paste that smallholders need to meet before their products can be paid for by a large scale user. In this case, to meet quantity requirements extension services need to help organise and pull raw materials from several smallholders in an orderly and transparent manner to ensure that they meet specific quantity requirements and gain enough trust in doing so that all the smallholders in the supplying group can perceive the extension service provider as an unbiased helper who has their interest at heart.

In order to work with smallholders to meet the demand for specific quality requirements, the challenge for extension services is to provide simple, easily verifiable quality monitoring support for its group of smallholders. The quality monitoring exercise must be known to the end-user who buys the raw material from the smallholder groups. The extension service also needs to ensure that the group understand how this exercise helps them to compete against others in meeting the needs of the end-user. The final task for extension services that would make this process sustainable is to work with the end-user to secure a befitting reward for compliance with quality requirement or conversely a befitting punishment for failure to comply with quality requirements. The preference should be towards rewarding compliance rather than punishing deviance.

\section{Working with a range of partners at different stages in the value chain to take pilot studies to scale}

Recent studies have indicated that there is a significant market potential for unfermented cassava flours as partial or total replacement for wheat in food and for the manufacturing of plywood and paperboard in industry (Day et al., 1996). In industry, the application of cassava flour to replace wheat flour is used by the plywood industry as glue extender, and possibly the industrial starch used in paper board. In spite of considerable research on bread making and the use of composite flours, there has been little impact on commercial practice (except where government controls wheat imports as in Nigeria in 2002 to 2008). The most promising food products for cassava flour substitution on account of simplicity are pies/pastries, cakes, biscuits and doughnuts.

Pilot studies by the Natural Resources Institute (NRI), United Kingdom; the International Institute of Tropical Agriculture (IITA), and their collaborators in West Africa (University of Agriculture, Abeokuta ad the Food Research Institute, Accra) on the pros and cons of different methods for organising processing and scales of production are just becoming widespread practices especially in Nigeria and Ghana. Small-scale processes using simple technology suited to village level enterprises have the advantage of being located very close to the production sites of cassava. This minimises the transport costs associated with the movement of large quantities of relatively cheaper cassava roots (Adebayo et al., 2009).

Ensuring that these successful pilot cases become widespread practice is undoubtedly the job of a functional extension service. The experience in C:AVA have 
shown that extension services cannot do it alone. They need to work all along the value chain with other partners including private investors, banks and insurance companies, standards and food and drugs administration agencies as well as their traditional allies in the technology transfer circle - researchers. The ability and willingness to collaborate in this manner would be to the advantage of smallholders who are often highly dependent of the extension service because of their long standing history of working together.

\section{Selecting and promoting appropriate technologies for different circumstances}

The C:AVA strategy focuses in particular on the technical and financial aspects of the value chain, for example improving processing techniques and assisting actors in gaining access to credit. While these appear to have worked very well in Nigeria and Ghana, the project design in Tanzania and possibly Uganda and Malawi should have given more attention to more intangible factors that determine the project's outcomes such as advocacy and publicity campaign to raise awareness and create support amongst politicians as well as consumers; facilitation of permanent producer platforms to strengthen linkages between value chain actors, disseminate market information and new technologies and raising awareness on costs and reasonable prices for HQCF and its intermediate products. This is because value chains for HQCF in the sense that have been found in Nigeria and Ghana in the last one and a half year have been found very weak or non-existent in Tanzania. Even in Uganda, C:AVA is only hoping that the interests currently generated will produce some rapid results in the sector.

As a contribution to building the value chain for HQCF in the Tanzania, and possibly Uganda and Malawi where the value chains for HQCF are relatively younger than Nigeria and Ghana, there is the need for C:AVA and others to actively provide financial support for rural processors for processing equipment until they have built the requisite skills (technical, business and entrepreneurial) and confidence to stimulate determined investments in the chain. The basis for this is that C:AVA experiences especially in Tanzania and partly in Uganda is that the circumstances under which smallholders operate differ between countries and in fact within countries and communities. For instance:

a. Unlike Nigeria, there is no deliberate government drive to make HQCF an important item in the government agenda.

b. Unlike Ghana and Nigeria, there is an absence of national or local champions leading the crusade to make HQCF a major player in the agenda

c. Unlike West Africa, the use of graters and presses in cassava processing is not widespread and where these machines are available, they are not made from stainless steel which is required for food grade products.

d. Particularly in Tanzania, the entrepreneurial spirit appears very low in the cassava sector and risk aversion appear rampant all through the chain from smallholder farmers to the potential end-users of HQCF.

In these varying circumstances, there is no 'quick fix' or formula for intervening in the HQCF value chain. Extension services need to fully understand the circumstances under which their smallholder groups operate and work within their peculiar limitation to recommend appropriate technologies for ensuring the 
sustainable inclusion of their smallholder groups in the value chain. It is also important for the extension services to prepare their smallholder group for taking on the next technological challenges within their peculiar circumstances.

\section{Anticipating negative effects of the market environment on smallholders}

The market environment is in a continuous state of flux. Larger actors often have larger capacities to absorb the shocks and variations in the market environment. Smallholders on the other hand, most of the time either do not have the resources or do not possess the required skills to cope with major movements in the large market. For instance, recent dynamics of the global economy is a factor influencing the cassava postharvest system. The impact of the global market for grains, fluctuating commodity prices including petroleum products are now showing its effects in the demand and supply of cassava. But extension services can and should help in this non-traditional aspect of their work. This may mean that extension officers themselves need to be provided additional training to understand the nature of the large market and prepare their smallholder groups to cope with its negative effects and take advantage of its positive ones.

\section{Ensuring that strategies for ensuring benefits for women and other disadvantaged groups are incorporated into extension service operations}

The cassava postharvest system has assigned gender roles. Several studies have shown that cassava processing is traditionally women's business in many smallholder situations (Afolami and Ajani, 1995); but more recent studies have shown that as cassava processing become more commercialised, men begin to own and run cassava processing enterprises (Adebayo et al , 2003). Extension services need to bear in mind at all times this power equation and how their intervention may shift its balance for or against one group or the other within their smallholder groups or communities. This way, extension services would prevent or at least prepare remedial actions for interventions in the HQCF value chain that may injure women or other groups who may be disadvantaged by it.

\section{Conclusions}

From the foregoing, it is evident that one strategy does not work in all countries. The development interventions in HQCF value chain need to provide a clear understanding of its social and development implications and trade-offs before initiating contacts with smallholders whose position in the system would make a negative outcome more devastating. Even so, it is important to note that there is no 'one size fits all' approach for addressing value chain development for HQCF. The social and cultural diversity that exists within each cassava growing country and communities are wide such that interventions that work in one cassava producing community may not work as well in a neighbouring one.

At this stage of its development in Africa, smallholders are an integral part of attempts to develop the value chain for HQCF. Unlike large scale commercial operators their business skills and ability to engage in any power tussle with larger actors in the value chain are low. This is a major challenge for extension service to act both as an unbiased facilitator and a trusty friend of smallholders in this attempt to ensure that they benefit from an emerging value chain with implications for their traditional practices and knowledge systems. 
Finally, while positive government support for cassava development is helpful, the real challenge is in the need for extension services to help its smallholder groups to target markets according to their realisable capacities in the value chain. Sustainable options for the inclusion of smallholders in the emerging HQCF value chain in Africa require a sensitive extension service that is willing to learn along with other actors in the value chain and at the same time share its knowledge of smallholder systems in an open and transparent way such that it gains confidence both frommjn its smallholder groups and other actors in the value chain. The extension service must accept that situations continue to change with time, actors and locations and must be willing and able to adapt as the situation requires in the interest of its smallholder groups. Consistent common sense and reasonable consideration of circumstances at any particular period in time often offer the best way forward.

\section{Acknowledgments}

The authors are grateful to the Bill and Melinda Gates Foundation who funded the Cassava: Adding Value for Africa (C:AVA) Project and to many services providers, consultants, collaborating enterprises and project beneficiaries whose inputs are central to achieving the charitable purpose of the project.

\section{References}

Adebayo, K. (2006). Dynamics of the Technology Adoption Process in Rural-Based Cassava Processing Systems in Southwest Nigeria. International Foundation for Science, Sweden.

Adebayo, K., Lamboll, R. I. and Westby, A. (2009) "Contextualizing Environmental, Social and Behavioral Issues in the Cassava Post-harvest System in Africa." Anthropologist Special Volume No. 5: 137-146

Adebayo, K., J. L White, M. J. Morris, A. O. Dipeolu, I. A. Ayinde, T. S. Wandschneider, L. O. Sanni, O. B. Oyewole, K. Tomlins and A. Westby (2003) "Innovativeness and stakeholdership in the fufu processing systems in southwest Nigeria". Agriculture, Social Science, Environment and Technology Series A, 3 (4):15-27

Afolami C.A. and Ajani O.I. (1995): 'Gender Participation, Group Formation and Adoption of Cassava Processing Technologies in Ogun State". In the Proceedings of the Eight Annual Conference of the Nigerian Rural Sociological Association (NRSA); held at Ogun State, Ago Iwoye. $13^{\text {th }}-17^{\text {th }}$ March 1994. pp 88-96.

Day G, Graffham A J. Ababio, J., Amoako M. (1996) Feasibility Study : Market potential for cassava-based flours and starch in Ghana. University of Ghana and NRI, Kent, U.K. University 28pp

Dipeolu, A., Adebayo, K., Ayinde, I. A., Oyewole, O. B., Sanni, L. O., Pearce, D. M., Wandschneider, T. S., White, J. L., Tomlins, K. and Westby, A. (2001). "Commercialisation of fufu: Some issues of marketing in Ogun and Lagos States of Nigeria". African Crop Science Proceedings Vol. 5, pp. 739-745

Dipeolu, A. O., Ayinde, I. A., Adebayo, K., Oyewole, O. B. , Sanni, L. O., Pearce, D. M., Wandschneider, T. S., White, J. L. and Westby, A. (2003). "Challenges facing the cassava processing industries in meeting urban food needs in Nigeria". Paper presented at the International Working Meeting Improving Food Systems in sub-Saharan Africa: Responding to a Changing Environment 
(FOOD-AFRICA) held at the Palais du Congress, Yaounde, Cameroon between $5^{\text {th }}-9^{\text {th }}$ May, 2003

NEPAD (2004) NEPAD targets cassava as Africa's top fighter against poverty. NEPAD Dialogue: Focus on Africa. Number 36, 27 February 2004. http://www.un.org/special-

rep/ohrlls/News_flash2004/NEPAD\%20Newsletter\%20English\%2036.htm

Sanni, L. O. (2005). Cassava Utilization and Regulatory Framework in Nigeria. Technical report submitted to United Nations Industrial Development Organization, Abuja, Project. Code: YA/RAF/03/447/17-51, December 2005.

Van Oirschot, Q., Ngendello, T. and Westby, A. (2004) Improving cassava processing for the market. LEISA Magazine, 20(3) - From Field to Market, pp 24-26.

http://www.leisa.info/FritZ/source/getblob.php?o_id=67773\&a_id=211\&a_seq=0

UNAAB (2007). Development of the Small and Medium Scale Enterprise Sector Producing Cassava Based Products to Meet Emerging Urban Demand in West Africa. The European Union, Brussels. 